\title{
High dietary iron reduces transporters involved in iron and manganese metabolism and increases intestinal permeability in calves
}

\author{
S. L. Hansen, ${ }^{*}$ M. S. Ashwell, ${ }^{*}$ A. J. Moeser, † R. S. Fry, ${ }^{*}$ M. D. Knutson, $\ddagger$ and J. W. Spears ${ }^{* 1}$ \\ ${ }^{*}$ Department of Animal Science, North Carolina State University, Raleigh 27695-7621 \\ †Department of Population Health and Pathobiology, North Carolina State University College of Veterinary Medicine, Raleigh 27695-8401 \\ ‡Food Science and Human Nutrition Department, University of Florida, Gainesville 32611
}

\section{ABSTRACT}

A 56-d experiment was designed to examine the effect of high dietary Fe on metal transporters involved in Fe and Mn metabolism. Fourteen weaned Holstein calves were stratified by weight and randomly assigned to 1 of 2 treatments: 1 ) no supplemental Fe (normal $\mathrm{Fe}$ ) or 2) $750 \mathrm{mg}$ of supplemental $\mathrm{Fe} / \mathrm{kg}$ of dry matter (high Fe). Jugular blood was collected on d 0, 35, and 56. At the end of the trial, 6 calves per treatment were humanely killed and duodenal scrapings, liver, and heart were collected for analysis. Additionally, proximal duodenum was mounted on Ussing chambers to assess intestinal barrier integrity. Calves receiving high dietary Fe displayed decreased transepithelial resistance and increased apical-to-basolateral flux of radiolabeled mannitol, suggesting that high Fe created increased intestinal permeability. Feeding calves a diet high in Fe decreased average daily gain, dry matter intake, and feed efficiency. Hemoglobin and serum Fe concentrations did not differ due to dietary treatment. High dietary Fe increased concentrations of $\mathrm{Fe}$ in the liver, but did not affect heart or duodenal Fe concentrations. Duodenal Mn concentrations were lowered by feeding a high Fe diet, but liver and heart Mn concentrations were not affected. As determined by real-time reverse transcription PCR, relative hepatic expression of the gene that encodes the Fe regulatory hormone hepcidin was 5 -fold greater in calves fed high dietary Fe. Hepcidin is released in response to increased Fe status and binds to the Fe export protein ferroportin causing ferroportin to be degraded, thereby reducing dietary Fe absorption. Confirmation of this result was achieved through Western blotting of duodenal protein, which revealed that ferroportin was decreased in calves fed high dietary Fe. Duodenal protein expression of divalent metal transporter 1 (DMT1), a Fe import protein that can also transport Mn, tended to be reduced by high dietary Fe. Transcript levels of several genes involved in

Received April 30, 2009.

Accepted October 26, 2009

${ }^{1}$ Corresponding author: jerry_spears@ncsu.edu
Fe metabolism in liver and duodenum were unchanged by treatment. In summary, feeding calves a diet high in Fe induced a signal cascade (hepcidin) designed to reduce absorption of $\mathrm{Fe}$ (via reduced protein expression of ferroportin and DMT1) in a manner similar to that reported in rodents. Additionally, reduced levels of DMT1 protein appeared to decrease duodenal Mn, suggesting that Mn may also be a substrate for DMT1 in cattle.

Key words: cattle, iron, manganese, metal transporter

\section{INTRODUCTION}

Cattle diets often contain high levels of Fe. High dietary $\mathrm{Fe}$ may result from feedstuffs that are high in $\mathrm{Fe}$ or from contamination by soil. Some common ruminant feedstuffs that can be high in $\mathrm{Fe}$ are alfalfa $(300 \mathrm{mg} /$ $\mathrm{kg}$ of DM), corn gluten feed (400 mg/ $\mathrm{kg}$ of DM), dried distillers grains with solubles $(600 \mathrm{mg} / \mathrm{kg}$ of DM), and soyhulls $(600 \mathrm{mg} / \mathrm{kg}$ of DM; NRC, 1996; Kerr et al., 2008).

Iron is an essential trace element and is required for several important biological processes; however, excessive Fe can lead to the production of free radicals and expose sensitive tissues to oxidative stress (Ganz and Nemeth, 2006). As a result of this delicate balance, nature has evolved a very complex system by which the body is able to regulate the absorption of dietary Fe. Two proteins in particular play an important role in modulation of Fe absorption, the cellular Fe importer divalent metal transporter 1 (DMT1) and the cellular Fe exporter ferroportin (FPN). We recently demonstrated the presence of these proteins in the duodenum of growing beef cattle (Hansen, 2008). In addition to transporting Fe, DMT1 can transport several other divalent metals, including Mn (Garrick et al., 2006). High dietary $\mathrm{Fe}$ decreased tissue $\mathrm{Mn}$ concentrations and tended to decrease intestinal levels of DMT1 and FPN in pigs, suggesting a possible role for DMT1 in the antagonism between $\mathrm{Fe}$ and $\mathrm{Mn}$ in the pig (Hansen, 2008). The role of DMT1 in this relationship is supported through work using cell culture and rodent 
Table 1. Ingredient composition of $\operatorname{diets}^{1}$

\begin{tabular}{|c|c|c|c|}
\hline Ingredient, $\%$ of DM & Starter & Grower 1 & Grower 2 \\
\hline Cottonseed hulls & 15.0 & 30.0 & 30.0 \\
\hline Ground corn & 57.1 & 49.0 & 47.8 \\
\hline Soybean meal & 24.0 & 13.0 & 15.8 \\
\hline Casein & - & 1.75 & - \\
\hline Limestone & 1.5 & 1.3 & 1.3 \\
\hline Rumensin ${ }^{2}$ & 1.25 & 1.25 & 1.25 \\
\hline White salt & 0.5 & 0.5 & 0.5 \\
\hline Urea & - & 0.45 & 0.6 \\
\hline Phosphoric acid $^{3}$ & 0.3 & 0.5 & 0.5 \\
\hline Trace mineral premix ${ }^{4}$ & 0.2 & 0.1 & 0.1 \\
\hline Vitamin premix ${ }^{5}$ & 0.1 & 0.1 & 0.1 \\
\hline Sucram $^{6}$ & 0.04 & 0.05 & 0.05 \\
\hline Corn supplement $^{7}$ & - & 2.0 & 2.0 \\
\hline
\end{tabular}

${ }^{1}$ Starter diet was provided in addition to milk through weaning and had an analyzed content of $60 \mathrm{mg}$ of Fe/ $\mathrm{kg}$ of DM; grower 1 diet was fed from d 0 through d 38 and had an analyzed content of $67 \mathrm{mg}$ of Fe/kg of DM; grower 2 diet was fed from d 38 through d 56 and had an analyzed content of $62 \mathrm{mg}$ of $\mathrm{Fe} / \mathrm{kg}$ of DM.

${ }^{2}$ Forumlated to provide $275 \mathrm{mg}$ of Rumensin per head per day (Rumensin for Dairy, Renaissance Nutrition, Roaring Spring, PA).

${ }^{3}$ Food grade, provided by Potash Corp., Aurora, NC.

${ }^{4}$ Starter provided per kilogram of diet: $40 \mathrm{mg}$ of $\mathrm{Zn}$ as $\mathrm{ZnSO}_{4} ; 40$ $\mathrm{mg}$ of $\mathrm{Mn}$ as $\mathrm{MnSO}_{4} ; 0.25 \mathrm{mg}$ of $\mathrm{I}$ as $\mathrm{Ca}\left(\mathrm{IO}_{3}\right)_{2}\left(\mathrm{H}_{2} \mathrm{O}\right) ; 0.2 \mathrm{mg}$ of Se as $\mathrm{Na}_{2} \mathrm{SeO}_{3}$; and $0.1 \mathrm{mg}$ of $\mathrm{Co}$ as $\mathrm{CoCO}_{3}$. Grower 1 and 2 diets were formulated to provide per kilogram of diet: $40 \mathrm{mg}$ of $\mathrm{Zn}$ as $\mathrm{ZnSO}_{4} ; 0.25$ $\mathrm{mg}$ of $\mathrm{I}$ as $\mathrm{Ca}\left(\mathrm{IO}_{3}\right)_{2}\left(\mathrm{H}_{2} \mathrm{O}\right) ; 0.2 \mathrm{mg}$ of Se as $\mathrm{Na}_{2} \mathrm{SeO}_{3} ; 0.1 \mathrm{mg}$ of $\mathrm{Co}$ as $\mathrm{CoCO}_{3} ; 28 \mathrm{mg}$ of $\mathrm{Mn}$ as $\mathrm{MnSO}_{4}$; and $4 \mathrm{mg}$ of $\mathrm{Cu}$ as $\mathrm{CuSO}_{4}$.

${ }^{5}$ Provided per kilogram of diet: 9,912 IU of vitamin A; 2,203 IU of vitamin $\mathrm{D}_{3}$; and $4.4 \mathrm{IU}$ of vitamin $\mathrm{E}$.

${ }^{6}$ Flavoring agent, provided by Pancosma, Geneva, Switzerland.

${ }^{7}$ Provided dietary Fe treatment.

models (Chua and Morgan, 1997; Gunshin et al., 1997); however, the molecular mechanisms behind the interactions between $\mathrm{Fe}$ and $\mathrm{Mn}$ have yet to be elucidated in ruminants. The objective of the present study was 3-fold: 1) to determine if duodenal and hepatic expression of certain gene products involved in Fe absorption in the young calf are affected by dietary Fe concentration, 2) to determine if high dietary Fe affects tissue Mn concentrations and 3) to determine if high dietary Fe affects duodenal mucosal integrity.

\section{MATERIALS AND METHODS}

\section{Animals and Experimental Design}

Care, handling, and sampling procedures were approved by the North Carolina State University Animal Care and Use Committee before initiation of the trial. Fourteen Holstein bull calves aged 1 to $7 \mathrm{~d}$ were purchased from a local commercial dairy farm. Calves were housed in individual hutches and fed whole milk until 8 wk of age, during which time they were allowed ad libitum access to a starter diet (Table 1). Approximately 1 wk before weaning, calves were moved from the hutches to individual pens, which provided approximately $3 \mathrm{~m}^{2}$ of pen space.

At weaning, calves were stratified by BW $(73.8 \pm 3.7$ $\mathrm{kg}$ ) and randomly assigned to 1 of 2 dietary treatments: 1) no supplemental Fe or 2) $750 \mathrm{mg}$ of supplemental $\mathrm{Fe} / \mathrm{kg}$ of DM (provided as $\mathrm{FeSO}_{4}$ ). Calves received the grower 1 diet from d 0 through d 38 and the grower 2 diet from d 39 through the end of the study (Table 1). The grower 2 diet was formulated without casein and contained slightly higher levels of soybean meal and urea. Calves were fed once daily, with feed amounts based on what they would consume in a 24 -h period. Ad libitum access to water was provided throughout the experiment. Diets were formulated to meet or exceed all NRC recommendations (NRC, 2001). Supplemental $\mathrm{Mn}$ and $\mathrm{Cu}$ were provided to meet the NRC recommendation when combined with $\mathrm{Mn}$ and $\mathrm{Cu}$ provided by dietary ingredients. The control grower 1 and 2 diets had analyzed contents of 67 and $62 \mathrm{mg}$ of $\mathrm{Fe} / \mathrm{kg}$ of DM, respectively.

\section{Sample Collection}

Body weights of calves were obtained on d 0, 35, and 56. Jugular blood samples were collected on d 0 , 35 , and 56 of the trial for analysis of serum Fe and hemoglobin. Blood for hemoglobin analysis was collected in heparinized vacuum tubes (Becton Dickinson, $\mathrm{Ru}-$ therford, NJ) and transferred on ice to the laboratory. Blood for serum analysis was collected in vacuum tubes and allowed to clot at room temperature for $1 \mathrm{~h}$ before centrifugation at $1,200 \times g$ for 20 min at $20^{\circ} \mathrm{C}$.

Six calves from each treatment group were randomly selected to be harvested at the termination of the study for tissue collection. Three calves per treatment were harvested on 2 consecutive days, the first group on $\mathrm{d} 57$ and the second group on d 58. Calves were transported approximately $11 \mathrm{~km}$ to the North Carolina State University College of Veterinary Medicine (Raleigh) for harvest. To avoid intestinal stress before tissue collection, calves were sedated via an i.v. dose of xylazine $(100 \mathrm{mg})$ and killed with an i.v. overdose of pentobarbital sodium.

Immediately following euthanasia, a midline incision was made in the duodenum and a $25-\mathrm{cm}$ section, approximately $10 \mathrm{~cm}$ distal to the pyloric sphincter, was removed and gently squeezed to remove digesta. Segments were cut open longitudinally along the antimesenteric border, rinsed briefly in water to remove any remaining digesta, and thoroughly rinsed with $0.87 \%$ saline before mucosal scrapings were collected. Scrapings were performed as described previously (Hansen et al., 2009). Sections of liver and heart (apex) were also collected. Tissue samples collected for mineral analysis 
were placed in Whirl-Pak bags (Nasco, Fort Atkinson, $\mathrm{WI}$ ) and placed on ice before storage at $-20^{\circ} \mathrm{C}$. All remaining tissue samples were flash frozen in liquid $\mathrm{N}_{2}$ to prevent protein and RNA degradation.

\section{Analytical Procedures}

Whole blood samples were analyzed for hemoglobin content using Drabkin's Reagent (Sigma Chemical Co., 1990) and a hemoglobin standard (Pointe Scientific, Canton, MI). Feed and tissue samples were dried in a forced air oven (Imperial II, Lab-Line Instruments, Melrose Park, IL) and prepared for mineral analysis by wet ashing using microwave digestion (Mars 5, CEM Corp., Matthews, NC) as described by Gengelbach et al. (1994). Mineral content of feed, serum, and tissues was determined by flame atomic absorption spectroscopy (model AA-6701F, Shimadzu Scientific Instruments, Kyoto, Japan). A bovine liver standard (1577b Bovine Liver, National Institute of Standards and Technology, Gaithersburg, MD) was included in all runs to verify instrument accuracy.

\section{Protein Extraction and Immunoblotting Procedures}

Isolation of proteins from duodenal scrapings and SDS-PAGE were performed as described previously (Hansen et al., 2009), and $130 \mu \mathrm{g}$ of protein isolate was loaded into each well. Samples for FPN analysis were not heated before electrophoresis. Following transfer and blocking, membranes were probed with one of the following antibodies overnight at $4^{\circ} \mathrm{C}$ : monoclonal mouse anti-DMT1 (Novus Biologicals, Littleton, CO; $2 \mu \mathrm{g} / \mathrm{mL})$, affinity-purified polyclonal rabbit antiFPN $(1 \mu \mathrm{g} / \mathrm{mL}, \mathrm{M}$. D. Knutson, University of Florida, Gainesville; Knutson et al., 2005), or affinity-purified polyclonal rabbit anti-solute carrier family 39 member $14($ ZIP14; $1 \mu \mathrm{g} / \mathrm{mL}$, M. D. Knutson, University of Florida, Gainesville). For hephaestin protein, membranes were probed for $1 \mathrm{~h}$ at room temperature with polyclonal mouse anti-hephaestin (Novus Biologicals; 1:1,000 dilution). A partial recombinant mouse DMT1 protein (Novus Biologicals) served as the positive control for DMT1 analysis, and bovine spleen isolate served as the positive control for FPN analysis.

After incubation with the primary antibody, membranes were washed several times in Tris-buffered saline containing $0.1 \%$ Tween 20, incubated for $30 \mathrm{~min}$ with the appropriate alkaline phosphatase-linked secondary antibody, and then washed several times with Trisbuffered saline containing $0.1 \%$ Tween 20. Membranes were rinsed 2 times with deionized $\mathrm{H}_{2} \mathrm{O}$ and then visualized using Lumi-Phos WB (Pierce, Rockford, IL). Images were captured on autoradiography film (Blue
Devil Autoradiography Film, Genesee Scientific, San Diego, CA), and band densities were semi-quantified using Image Quant TL software (Amersham Biosciences, Piscataway, NJ). Membranes were stripped with Restore Western Blot Stripping Buffer Plus (Pierce) and reprobed with $\beta$-actin (Abcam, Cambridge, MA; 1:5,000 dilution for $1 \mathrm{~h}$ at room temperature) as a loading control.

\section{RNA Isolation and Real-Time Reverse Transcription-PCR}

Methods for RNA isolation, real-time reverse transcription (RT)-PCR, and computation of data were as previously reported (Hansen et al., 2009). Primer information is shown in Supplemental Table 1 (available online at http://www.journalofdairyscience.org/). Primers were designed using Primer-BLAST (http:// www.ncbi.nlm.nih.gov/tools/primer-blast/) for Fpn, Dmt1 without an iron responsive element (IRE) $(\boldsymbol{D} \boldsymbol{m t 1} \mathbf{I R E})$, and Dmt1 with an IRE $(\boldsymbol{D} \boldsymbol{m t 1}+\boldsymbol{I R E})$. Primers for hepcidin (Hamp), Zip14, superoxide dismutase 1 (Sod1), and superoxide dismutase 2 (Sod2) were designed using Beacon Designer 7 (Premier Biosoft International, Palo Alto, CA). Ribosomal protein S9 $(\boldsymbol{R p s} 9)$ was used as a housekeeping gene in all tissues; Rps9 primer information was previously reported by Janovick-Guretzky et al. (2007).

\section{Ussing Chamber Experiments}

Segments of proximal duodenum were harvested from the calves and the mucosa was stripped from the seromuscular layer in oxygenated $\left(95 \% \mathrm{O}_{2} / 5 \% \mathrm{CO}_{2}\right)$ Ringer's solution (mmol/L: $\mathrm{Na}^{+}, 154 ; \mathrm{K}^{+}, 6.3 ; \mathrm{Cl}^{-}, 137$; $\left.\mathrm{H}_{2} \mathrm{PO}_{4}, 0.3 ; \mathrm{Ca}, 1.2 ; \mathrm{Mg} \mathrm{0.7} ; \mathrm{HCO}_{3}^{-}, 24 ; \mathrm{pH} 7.4\right)$. Tissues were then mounted in Ussing chambers with a 1.13 $\mathrm{cm}^{2}$ aperture, as described in previous studies (Moeser et al., 2007). Tissues were bathed on the serosal and mucosal sides with $10 \mathrm{~mL}$ of Ringer's solution. The serosal bathing solution contained $10 \mathrm{~m} M$ glucose, which was osmotically balanced on the mucosal side with 10 $\mathrm{m} M$ mannitol. Bathing solutions were oxygenated (95\% $\mathrm{O}_{2} / 5 \% \mathrm{CO}_{2}$ ) and circulated in water-jacketed reservoirs maintained at $37^{\circ} \mathrm{C}$. The spontaneous potential difference (PD) was measured using Ringer-agar bridges connected to calomel electrodes, and the PD was shortcircuited through $\mathrm{Ag}-\mathrm{AgCl}$ electrodes using a voltage clamp that corrected for fluid resistance. Tissues were maintained in the short-circuited state, except for brief intervals to record the open-circuit PD. Transepithelial electrical resistance $\left(\right.$ TER, $\Omega \cdot \mathrm{cm}^{2}$ ) was calculated from the spontaneous PD and short-circuit current $\left(I_{\mathrm{sc}}\right)$, as described previously (Moeser et al., 2007) After a 30- 
min equilibration period on Ussing chambers, TER was recorded at 15 -min intervals over a 60 -min period and then averaged to derive the basal TER values for a given animal.

Mucosal-to-serosal fluxes of ${ }^{3} \mathrm{H}$-labeled mannitol were performed at the same time TER was measured. After a 15 -min period on Ussing chambers, $0.2 \mu \mathrm{Ci} / \mathrm{mL}$ of ${ }^{3}$ H-labeled mannitol (180 kDa; Sigma Chemical, St. Louis, MO) was added to the mucosal side of Ussing chamber-mounted tissues. The isotope was allowed to equilibrate for $15 \mathrm{~min}$ after which standards were taken from the mucosal side of each chamber $(t=30 \mathrm{~min})$, and a 60 -min flux period was established by taking $0.5-\mathrm{mL}$ samples from the serosal compartment at the beginning and end of the $60-$ min flux period. The presence of ${ }^{3} \mathrm{H}$ and ${ }^{14} \mathrm{C}$ was established by measuring $\beta$-emission in a liquid-scintillation counter (LKB Wallac, model 1219 Rack Beta, Perkin Elmer Life and Analytical Sciences Inc., Boston, MA), taking into account the differing curves and peaks of each isotope as determined by the scintillation counter. Unidirectional ${ }^{3} \mathrm{H}$-labeled mannitol mucosal-to-serosal fluxes were evaluated by determining mannitol-specific activity added to the mucosal bathing solution, and calculating the net appearance of ${ }^{3} \mathrm{H}$ over time in the serosal bathing solution on a chamber unit area basis.

\section{Oxidative Stress Measures}

Liver, intestine, and heart samples were analyzed in duplicate for malonyldialdehyde (MDA) using a commercially available kit (Lipid Peroxidation Assay Kit, Oxford Biomedical, Oxford, MI). Heart and liver samples were analyzed for glutathione peroxidase (GSH-Px) activity as described by Paglia and Valentine (1967).

\section{Statistical Analysis}

Performance and blood data were analyzed statistically by ANOVA for a completely randomized design using the MIXED procedure of SAS (SAS Institute Inc., Cary, NC) according to the following model

$$
\mathrm{Y}_{\mathrm{ij}}=\mu+\beta \mathrm{X}_{\mathrm{i}}+\mathrm{C}_{\mathrm{j}}+\mathrm{c}_{\mathrm{ij}}+\mathrm{E}_{\mathrm{ij}},
$$

where $Y_{i j}=$ dependent variable, $\mu=$ overall mean, $\beta X_{i}$ $=$ covariate coefficient, $\mathrm{C}_{\mathrm{j}}=$ fixed effect of jth treatment, $\mathrm{j}=1,2 ; \mathrm{c}_{\mathrm{ij}}=$ random effect of calf within $\mathrm{jth}$ treatment, $\mathrm{j}=1, \ldots, 14$; and $\mathrm{E}_{\mathrm{ij}}=$ random residual. Day $0 \mathrm{BW}$ was used in a covariate analysis for d $56 \mathrm{BW}$ and daily DMI data. Tissue mineral, protein, and mRNA data were analyzed using the MIXED procedure of SAS using the same model as performance data; however, there were no covariate terms in the model, and $\mathrm{c}_{\mathrm{ij}}=$ random effect of calf within jth treatment, $\mathrm{j}=1, \ldots, 12$. Individual animal served as the experimental unit for all data. Significance was declared at $P \leq 0.05$, and because of low animal numbers, tendencies are discussed at $P \leq 0.15$. Least squares means and pooled standard errors are presented, where $\mathrm{n}=7$ calves per treatment for performance and blood measurements, and $n=6$ calves per treatment for all tissue data. Cycle threshold $\left(\mathbf{C}_{t}\right)$ values for real-time RT-PCR were calculated and statistically analyzed as previously reported (Hansen et al., 2009). Lower $C_{t}$ values are indicative of higher transcript levels, such that samples with high levels of transcript will take a smaller number of PCR cycles to exceed the threshold value than samples expressing low levels of transcript (Hansen et al., 2009).

\section{RESULTS}

\section{Performance}

Weight gain, DMI, and feed efficiency for the 56-d period are shown in Table 2 . Feeding calves a diet high in Fe reduced ADG $(P=0.01)$, daily DMI $(P=0.02)$, and efficiency of feed conversion $(P=0.03)$.

\section{Blood and Tissue Mineral Analysis}

Hemoglobin, hematocrit, and serum Fe did not differ between treatments at any time point during the experiment (Table 3). Iron, Mn, and Zn concentrations in liver, duodenal, and heart tissue are presented in Table 4. High dietary Fe increased Fe concentrations in liver $(P=0.03)$ but not in heart or duodenum. Manganese concentrations were reduced $(P=0.05)$ in duodenal tissue in calves receiving high dietary Fe; however, liver and heart Mn concentrations were not affected by treatment. Liver, duodenum, and heart Zn concentrations were not affected by dietary Fe concentration.

\section{Tissue Measures of Oxidative Stress}

Activity of MDA in duodenal scrapings, liver, and heart did not differ between the dietary Fe treatments (Supplemental Table 2; available online at http://www. journalofdairyscience.org/). Similarly, GSH-Px activity in liver and heart was not affected by dietary Fe concentration (Supplemental Table 2; available online at http://www.journalofdairyscience.org/). Expression of heart Sod1 mRNA was increased 1.7 -fold $(P=0.004)$ in calves fed high dietary Fe compared with those fed normal levels of dietary Fe (Figure 1). Heart Sod2 mRNA expression was increased 1.5 -fold $(P=0.03)$ in calves fed high dietary Fe compared with those fed normal levels of Fe (Figure 1). 
Table 2. Effect of adequate or high dietary iron on gain, dry matter intake, and feed efficiency of calves ${ }^{1}$

\begin{tabular}{|c|c|c|c|c|}
\hline \multirow[b]{2}{*}{ Item } & \multicolumn{2}{|c|}{ Treatment $^{2}$} & \multirow[b]{2}{*}{$\mathrm{SEM}^{3}$} & \multirow[b]{2}{*}{$P$-value } \\
\hline & Control & High Fe & & \\
\hline Initial BW, $\mathrm{kg}$ & 73.3 & 74.4 & 3.66 & 0.75 \\
\hline Final $\mathrm{BW},{ }^{4} \mathrm{~kg}$ & 118.8 & 105.5 & 4.38 & 0.01 \\
\hline $\mathrm{ADG}, \mathrm{kg}$ & 1.01 & 0.79 & 0.05 & 0.01 \\
\hline $\begin{array}{l}\mathrm{ADM},{ }^{4} \mathrm{~kg} \\
\mathrm{Dg} / \mathrm{d}\end{array}$ & $\begin{array}{l}1.01 \\
3.26\end{array}$ & $\begin{array}{l}0.19 \\
2.92\end{array}$ & 0.17 & $\begin{array}{l}0.01 \\
0.02\end{array}$ \\
\hline Gain:feed & 0.28 & 0.23 & 0.01 & 0.03 \\
\hline
\end{tabular}

\section{Protein and Gene Expression in Duodenum and Liver}

Intestinal expression of DMT1, FPN, hephaestin, and ZIP14 proteins is depicted in Figure 2A. Intestinal levels of DMT1 tended $(P=0.13)$ to be reduced by high dietary Fe. Ferroportin levels were lower $(P=0.03)$ in calves fed high Fe. Levels of hephaestin and ZIP14 protein did not differ due to dietary treatment $(P=0.67$ and $P=0.47$, respectively). Intestinal mRNA levels of Dmt1+IRE, Dmt1-IRE, Fpn, and Zip14 are shown in Figure $2 \mathrm{~B}$ and were not different among treatments $(P$ $=0.13$ to $P=0.93$ ).

Hepatic levels of FPN and ZIP14 protein were not affected by dietary treatment $(P=0.24$ and $P=0.36$, respectively; Figure 3A). Transcript levels of $D m t 1+I R E$, Dmt1-IRE, Fpn, and Zip14 in liver did not differ due to dietary treatment $(P=0.66$ to $P=0.92$; Figure 2B). Hepatic Hamp mRNA was 5.2-fold greater $(P=$ 0.002) in calves fed high dietary Fe relative to calves fed normal dietary Fe (Figure 3B). The level of Hamp mRNA was negatively correlated with intestinal FPN protein expression $(\mathrm{r}=-0.60 ; P=0.07)$.

\section{Ussing Chamber Experiments}

Transepithelial electrical resistance was lower $(P<$ 0.01 ) in calves fed high dietary Fe (Figure 4A). Additionally, ${ }^{3} \mathrm{H}$-mannitol flux was greater $(P=0.04)$ due to high dietary $\mathrm{Fe}$ (Figure 4B) overall, indicating that high dietary Fe feeding had a deleterious effect on intestinal barrier function in calves.

\section{DISCUSSION}

Feeding a diet high in Fe (approximately $800 \mathrm{mg} / \mathrm{kg}$ of DM) to calves for $56 \mathrm{~d}$ decreased gain and affected proteins involved in Fe metabolism. The recommended dietary requirement of cattle for $\mathrm{Fe}$ is $50 \mathrm{mg} / \mathrm{kg}$ of DM (NRC 1996, 2001); however, the amount of Fe in cattle diets is often much greater. Superfluous dietary Fe may come from a variety of sources, including numerous ruminant feed ingredients such as dicalcium phosphate $(\sim 10,000 \mathrm{mg}$ of $\mathrm{Fe} / \mathrm{kg}$ of DM) and soyhulls $(\sim 600 \mathrm{mg}$ of $\mathrm{Fe} / \mathrm{kg}$ of DM; Kerr et al., 2008). In addition, many grasses contain greater than $100 \mathrm{mg}$ of $\mathrm{Fe} / \mathrm{kg}$ of DM, and legumes such as alfalfa and white clover have been

Table 3. Effect of adequate or high dietary iron on blood and serum iron measures in calves $^{1}$

\begin{tabular}{|c|c|c|c|c|}
\hline \multirow[b]{2}{*}{ Item } & \multicolumn{2}{|c|}{ Treatment $^{2}$} & \multirow[b]{2}{*}{$\mathrm{SEM}^{3}$} & \multirow[b]{2}{*}{$P$-value } \\
\hline & Control & High Fe & & \\
\hline \multicolumn{5}{|c|}{ Hemoglobin, g/dL } \\
\hline Day 35 & 12.2 & 13.4 & 0.58 & 0.19 \\
\hline Day 56 & 10.3 & 10.8 & 0.48 & 0.50 \\
\hline \multicolumn{5}{|c|}{ Hematocrit, \% } \\
\hline Day 35 & 23.2 & 25.4 & 1.45 & 0.32 \\
\hline Day 56 & 24.0 & 25.6 & 1.13 & 0.35 \\
\hline \multicolumn{5}{|c|}{ Serum Fe, mg/L } \\
\hline Day 35 & 1.69 & 1.28 & 0.17 & 0.11 \\
\hline Day 56 & 1.65 & 1.62 & 0.14 & 0.88 \\
\hline
\end{tabular}

${ }^{1}$ Calves received experimental diets for $56 \mathrm{~d}$.

${ }^{2}$ Control: no supplemental Fe (grower 1 contained $67 \mathrm{mg}$ of Fe/kg, grower 2 contained $62 \mathrm{mg}$ of $\mathrm{Fe} / \mathrm{kg}$ ); High Fe: $750 \mathrm{mg}$ of supplemental Fe/kg.

${ }^{3}$ Pooled standard error of the mean ( $\mathrm{n}=7$ per treatment). 


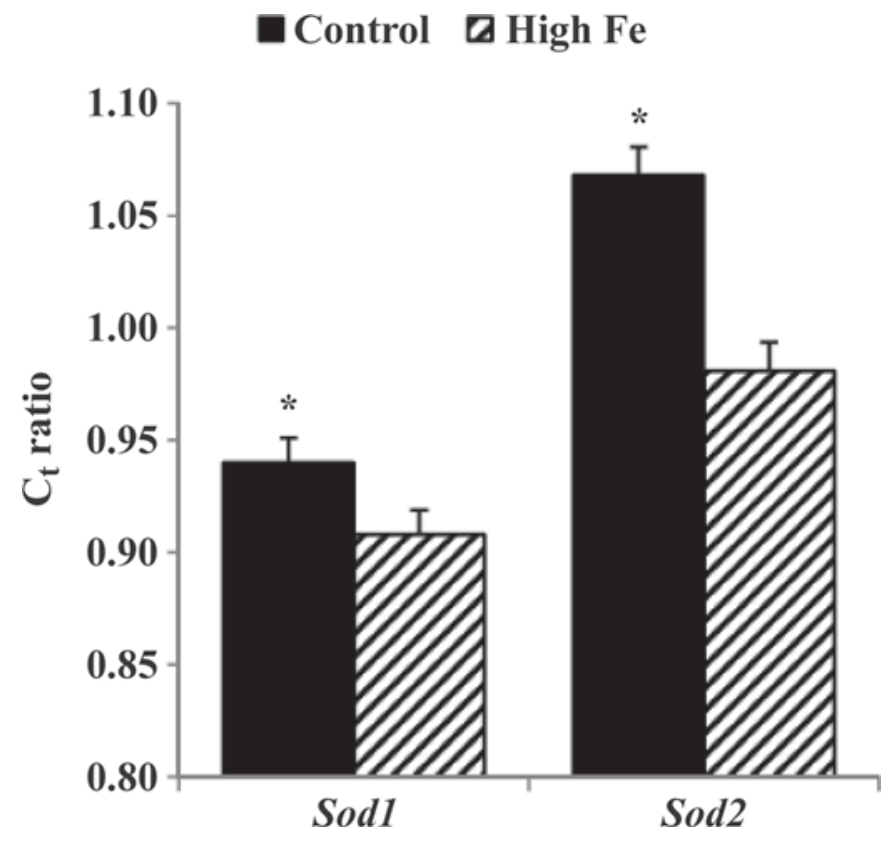

Figure 1. Expression of superoxide dismutase 1 and 2 (Sod1 and Sod2) mRNA in calf heart is increased due to high dietary iron (LSM \pm pooled SEM; $\mathrm{n}=6$ per treatment). Expression is shown as a cycle to threshold $\left(\mathrm{C}_{t}\right)$ ratio, where a lower $\mathrm{C}_{\mathrm{t}}$ ratio indicates greater mRNA expression. ${ }^{*}$ Treatments are different $(P<0.05)$.

reported to contain greater than $200 \mathrm{mg}$ of $\mathrm{Fe} / \mathrm{kg}$ of DM (NRC, 1996; Greene, 2000). Soil contamination represents an additional source of dietary Fe: we previously demonstrated that a fraction of $\mathrm{Fe}$ in soil does become soluble in the ruminant digestive system and may be small enough to be absorbed by the animal (Hansen and Spears, 2009).
In the present study, feeding calves a diet high in $\mathrm{Fe}$ decreased daily weight gain, daily DMI, and feed efficiency. Standish et al. (1969) also reported a negative relationship between increasing levels of supplemental Fe $(0,400$, and $1,600 \mathrm{mg} / \mathrm{kg}$ of $\mathrm{DM})$ and $\mathrm{DM}$ intake in growing beef steers. Those authors observed a linear decrease in average daily gain over a $77-d$ period as supplemental Fe levels increased. Other studies have also shown a depressive effect of high dietary Fe on feed intake and gain (Koong et al., 1970; Standish et al., 1971). It is possible that the large amount of $\mathrm{FeSO}_{4}$ in the high $\mathrm{Fe}$ diet in the current study reduced the palatability of the diet, resulting in lower DMI and gain. Additionally, high dietary Fe may have affected ruminal fermentation, as in vitro work has suggested that high Fe reduces ruminal DM digestibility (Harrison et al., 1992). The source of Fe used in the present study, $\mathrm{FeSO}_{4}$, represents a highly soluble form of supplemental Fe. It is possible that use of a less soluble form of supplemental Fe, such as Fe carbonate, or a highly insoluble form, such as ferric oxide, might have affected the feed intake and efficiency of gain of these calves in a different manner.

Feeding calves a diet high in Fe for $56 \mathrm{~d}$ did not affect serum Fe concentrations, and only minor tissue Fe increases were observed, suggesting that Fe absorption was reduced in these calves. Our laboratory recently demonstrated the presence of several proteins important in Fe absorption in bovine duodenum (Hansen, 2008). Ferroportin, the only known exporter of Fe from the cell, is a membrane-bound protein localized to the basolateral portion of the enterocyte (Wessling-Resnick, 2006). Duodenal FPN concentrations were reduced in calves fed high dietary $\mathrm{Fe}$, possibly in an attempt to

Table 4. Effect of adequate or high dietary iron on iron, manganese, and zinc concentrations in liver, duodenum, and heart of calves ${ }^{1}$

\begin{tabular}{lrrrr}
\hline & \multicolumn{2}{c}{ Treatment $^{2}$} & & \\
\cline { 2 - 3 } Item & Control & High Fe & SEM $^{3}$ & $P$-value \\
\hline Liver, $\mathrm{ng} / \mathrm{kg}$ of DM & & & & \\
Fe & 116.8 & 152.9 & 10.98 & 0.03 \\
Mn & 11.1 & 11.4 & 0.64 & 0.67 \\
Zn & 136.2 & 148.8 & 13.36 & 0.40 \\
Duodenum, mg/kg of DM & & & & \\
Fe & 224.8 & 297.5 & 57.13 & 0.39 \\
Mn & 10.7 & 7.4 & 1.05 & 0.05 \\
Zn & 90.2 & 96.4 & 5.93 & 0.48 \\
Heart, mg/kg of DM & & & & \\
Fe & 179.7 & 194.3 & 6.68 & 0.16 \\
Mn & 4.7 & 4.2 & 0.71 & 0.60 \\
Zn & 95.2 & 89.3 & 2.45 & 0.13 \\
\hline
\end{tabular}

${ }^{1}$ Calves received experimental diets for $56 \mathrm{~d}$.

${ }^{2}$ Control: no supplemental Fe (grower 1 contained $67 \mathrm{mg}$ of $\mathrm{Fe} / \mathrm{kg}$, grower 2 contained $62 \mathrm{mg}$ of $\mathrm{Fe} / \mathrm{kg}$ ); High Fe: $750 \mathrm{mg}$ of supplemental $\mathrm{Fe} / \mathrm{kg}$.

${ }^{3}$ Pooled standard error of the mean $(\mathrm{n}=6$ per treatment). 

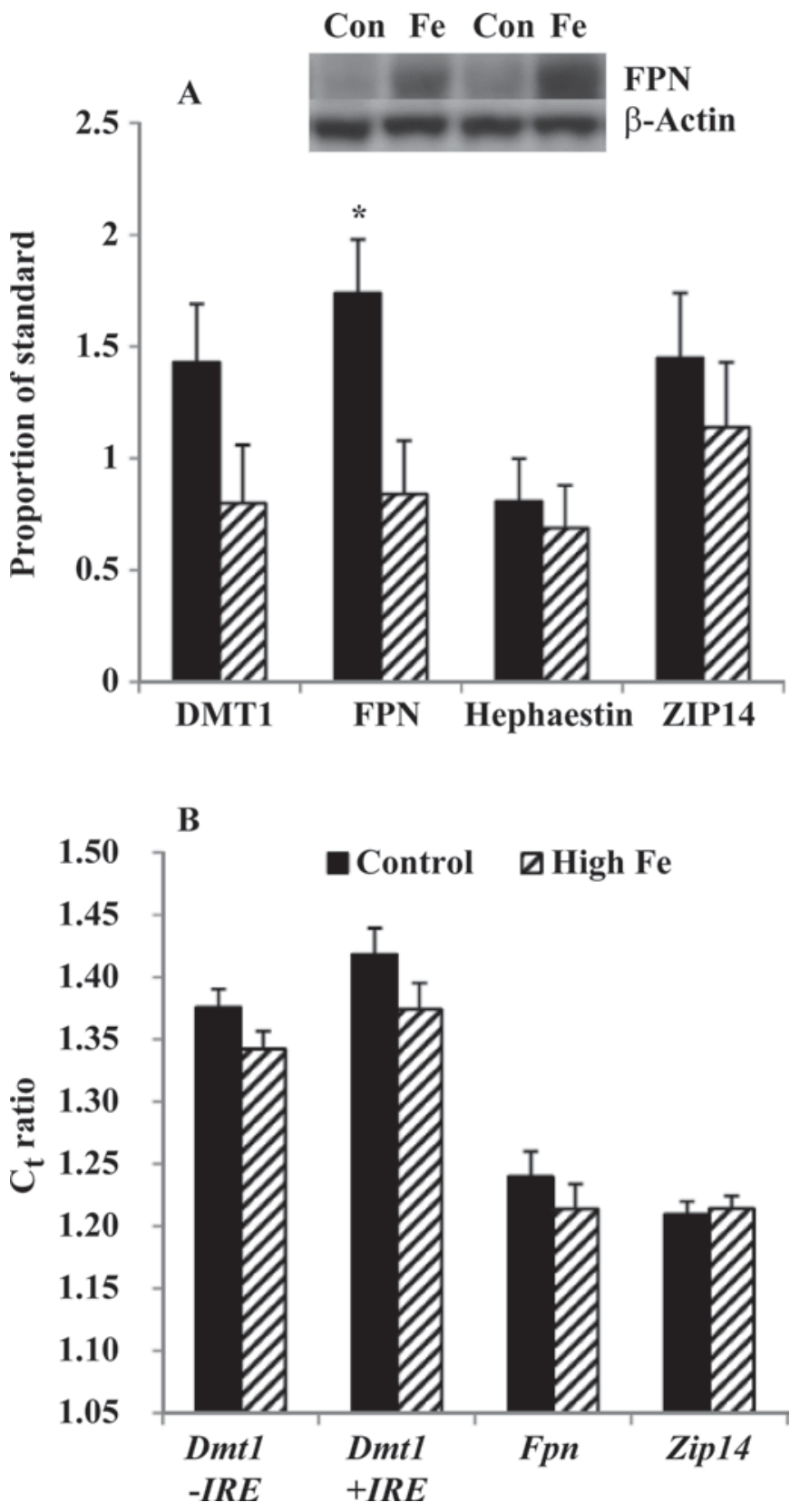

Figure 2. Effect of adequate (control, Con) and high dietary iron $(\mathrm{Fe})$ on intestinal expression (means \pm pooled SEM; $\mathrm{n}=6$ per treatment) of proteins (A) and genes (B) involved in iron metabolism in calves. Expression is shown as a cycle to threshold $\left(\mathrm{C}_{\mathrm{t}}\right)$ ratio, where a lower $\mathrm{C}_{t}$ ratio indicates greater mRNA expression. ${ }^{*}$ Treatments are different $(P<0.05)$. DMT1/Dmt $1=$ divalent metal transporter 1 ; FPN $/ F p n=$ ferroportin; ZIP14/Zip14 = zinc transporter family 39 member $14 ; \mathrm{IRE}=$ iron responsive element.

reduce Fe export into plasma. Ferroportin levels are mediated by the release of hepcidin, a small peptide released from the liver in situations of high Fe. Hepcidin binds to FPN causing it to be internalized and degraded to decrease export of Fe into plasma (Nemeth et al., 2004). A 5-fold increase in hepcidin gene expres- sion in calves receiving high dietary Fe likely resulted in the observed reduction in intestinal ferroportin protein in high Fe calves relative to controls.

There was a tendency for DMT1 protein to be lower in calves receiving high dietary $\mathrm{Fe}$, which could also have contributed to reduced Fe absorption in these calves. Divalent metal transporter 1 is a membranebound $\mathrm{H}^{+}$/divalent metal co-transporter localized to the apical surface of the enterocyte that serves as an importer of non-transferrin-bound Fe into cells (Hubert and Hentze, 2002). In rodents, some isoforms of Dmt1 mRNA contain an IRE in the $3^{\prime}$ untranslated region, allowing for regulation by intracellular $\mathrm{Fe}$ concentrations. Iron regulatory proteins become active when Fe status is low and bind to the IRE, increasing the half-life of Dmt1 mRNA (Garrick et al., 2006). Two putative Bos taurus Dmt1 isoforms are reported in the NCBI database (http://www.ncbi.nlm.nih.gov/), one that contains an IRE and one that does not. Our work suggests that genes encoding both isoforms are equally expressed within liver and duodenal tissue (Figures 2B and $3 \mathrm{~B}$ ). This is in contrast to rodent species, in which the primary isoform in duodenum and liver is the IREcontaining isoform of Dmt1 (Garrick et al., 2003). It is unclear why expression of either isoform of Dmt1 was not affected by high dietary $\mathrm{Fe}$, although it is possible that regulation is not entirely due to transcriptional changes but rather to posttranslational changes. Johnson et al. (2005) reported that incubation of Caco-2 cells with $100 \mu M$ of Fe for just $4 \mathrm{~h}$ caused DMT1 to be removed from the plasma membrane and relocated to intracellular compartments. Those authors also reported that total cellular DMT1 protein levels, determined by Western blotting, did not differ because of $\mathrm{Fe}$ exposure. This suggests that Fe absorption via DMT1 may be reduced through intracellular redistribution of the protein. In the present study, total cellular protein expression of DMT1 was examined, so it is possible that DMT1 in calves receiving the high Fe diet may have actually been located inside the cell, and therefore unable to transport $\mathrm{Fe}$ or $\mathrm{Mn}$ into the cell from the small intestine lumen. In the future, immunohistochemistry with an anti-DMT1 antibody could be used to determine if DMT1 is located within the cell or on the plasma membrane.

Few studies have evaluated the effects of high Fe on Mn metabolism in cattle. Standish et al. (1971) reported that beef steers consuming diets containing 1,000 $\mathrm{mg}$ of $\mathrm{Fe} / \mathrm{kg}$ of DM had lower concentrations of $\mathrm{Mn}$ in the heart. They found a numerical decrease in the apparent absorption of Mn compared with steers fed diets containing $100 \mathrm{mg}$ of $\mathrm{Fe} / \mathrm{kg}$ of DM, suggesting that $\mathrm{Fe}$ and Mn may share a similar transport mechanism. In the present study, feeding a diet high in Fe to calves 
A

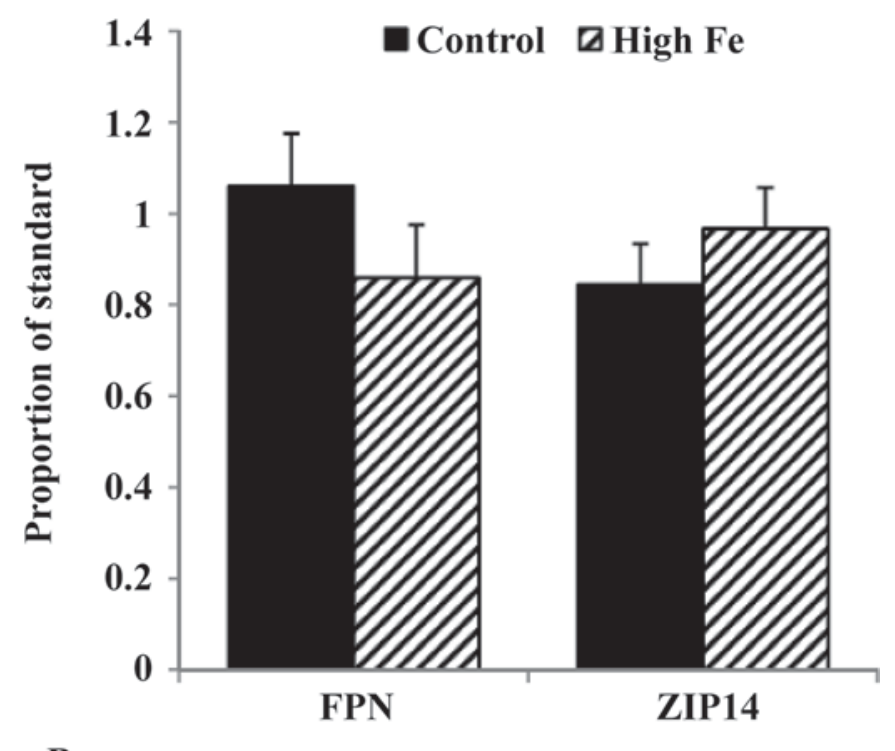

B

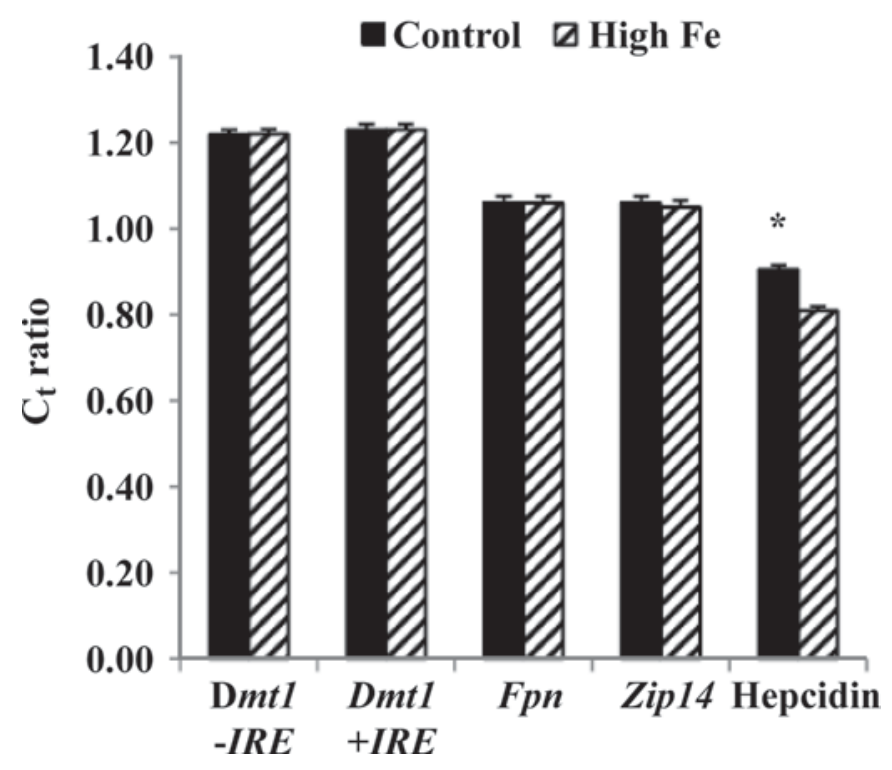

Figure 3. Effect of adequate and high dietary iron on liver expression (means \pm pooled SEM; $\mathrm{n}=6$ per treatment) of proteins $(\mathrm{A})$ and genes (B) involved in iron metabolism in calves. Expression is shown as a cycle to threshold $\left(\mathrm{C}_{t}\right)$ ratio, in which a lower $\mathrm{C}_{\mathrm{t}}$ ratio indicates greater mRNA expression. ${ }^{*}$ Treatments are different $(P<0.05)$. Dmt 1 $=$ divalent metal transporter $1 ; \mathrm{FPN} / F p n=$ ferroportin; ZIP14/Zip14 $=$ zinc transporter family 39 member 14 ; IRE $=$ iron responsive element.

reduced duodenal concentrations of Mn but did not affect liver Mn concentrations. It is possible that feeding this diet for $56 \mathrm{~d}$ did not allow sufficient time for initial Mn stores in the liver to be depleted. Previously in our laboratory we observed a negative relationship between dietary Fe concentrations and tissue Mn concentrations in weaned pigs fed 20,120 , or $520 \mathrm{mg}$ of $\mathrm{Fe} / \mathrm{kg}$ of $\mathrm{DM}$
A

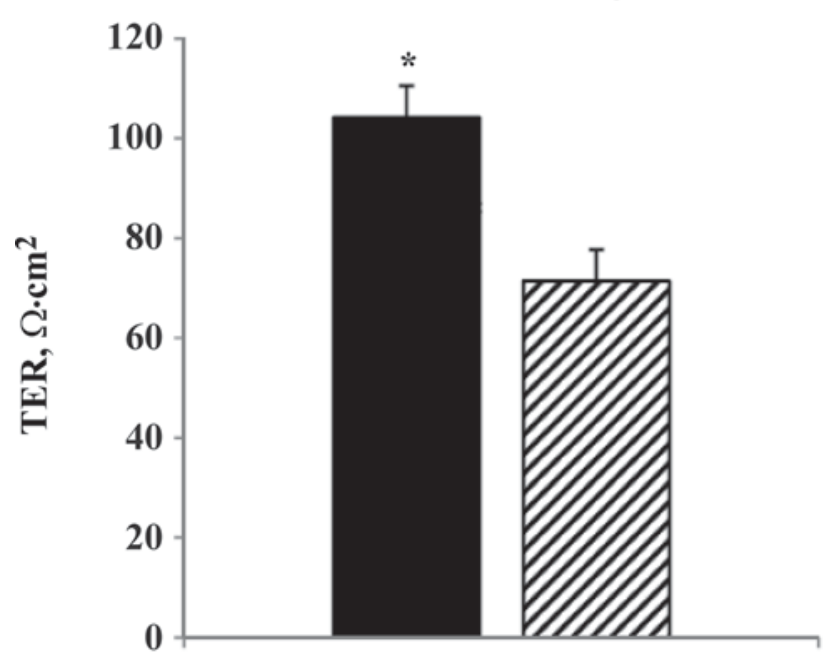

B

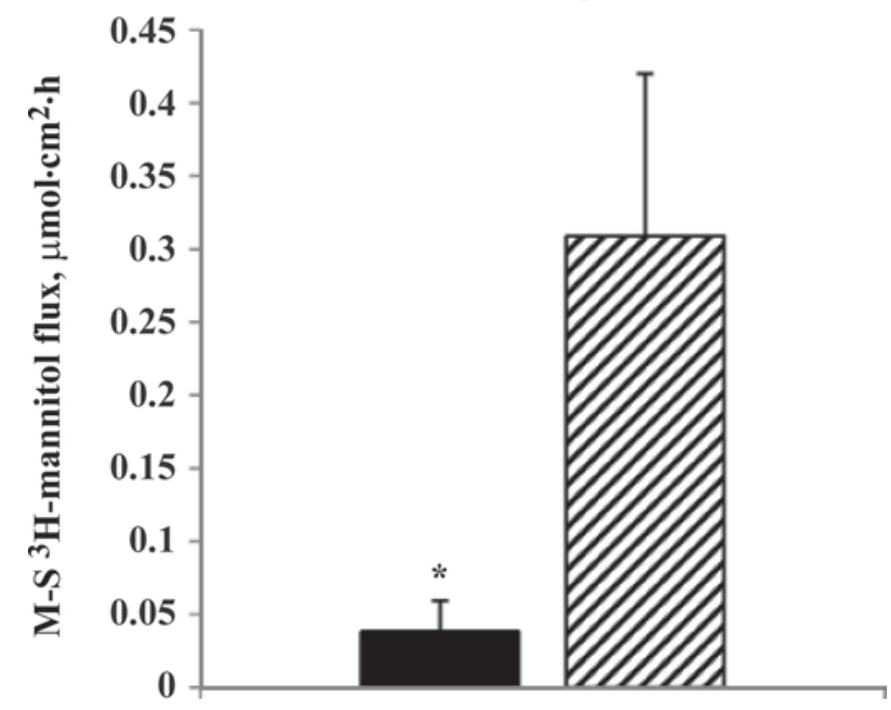

Figure 4. Effect of adequate or high dietary iron on gut integrity in calves, as measured by intestinal permeability (means \pm SEM; $\mathrm{n}=6$ per treatment). A) Duodenal transepithelial electrical resistance (TER); B) duodenal mucosal-to-serosal (M-S) ${ }^{3} \mathrm{H}$-mannitol flux. *Treatments are different $(P<0.05)$.

for $32 \mathrm{~d}$. Duodenal and liver Mn concentrations were lower in pigs fed diets containing $520 \mathrm{mg}$ of $\mathrm{Fe} / \mathrm{kg}$ of DM compared with those fed diets containing $20 \mathrm{mg}$ of $\mathrm{Fe} / \mathrm{kg}$ of DM (Hansen, 2008). Additionally, duodenal Dmt1 mRNA expression was depressed in pigs fed high dietary Fe.

In vitro work has indicated that DMT1 is capable of transporting $\mathrm{Mn}$ in addition to Fe (Gunshin et al., 1997), suggesting that Mn absorption may be impaired if DMT1 expression is decreased. Two lines of rodents, the microcytic mouse and the Belgrade rat, are sponta- 
neous mutants of DMT1 that suffer from Fe deficiency as a result of impaired Fe transport (Andrews, 1999). Metabolism of Mn has also been shown to be detrimentally affected in the Belgrade rat, indicating that the Dmt1 gene mutation is causing disruption in absorption of Mn as well as that of $\mathrm{Fe}$ (Chua and Morgan, 1997). In addition, Conrad et al. (2000) reported that Mn uptake in a normal cell line (HEK-293) was reduced in a linear fashion when DMT1 activity was blocked by increasing amounts of DMT1 antibody, further supporting the role of DMT1 in Mn absorption. Collectively, the data in the present study along with our previous findings in pigs suggest that DMT1 may play a role in Fe and Mn absorption in both pigs and cattle.

The current study is the first to demonstrate the presence of ZIP14, a known Zn and Fe importer, in ruminants. Increased dietary $\mathrm{Fe}$ did not affect tissue Zn concentrations or transcript or protein expression of ZIP14 in either the duodenum or liver. Conversely, we have previously shown that the transcript level of duodenal Zip14 was decreased when pigs were fed 520 $\mathrm{mg}$ of $\mathrm{Fe} / \mathrm{kg}$ of DM compared with those fed $20 \mathrm{mg}$ of $\mathrm{Fe} / \mathrm{kg}$ of DM (Hansen, 2008). Differences in Fedependent regulation of Zip14 transcript and ZIP14 protein between pigs and cattle may relate to ruminal effects on Fe metabolism when a high-Fe diet is fed. At harvest, a dramatic difference in rumen papillae color was observed in calves fed high Fe relative to controls. Whereas control calves were observed to have normally colored rumen papillae, high-Fe calves had black papillae (Supplemental Figure 1; available online at http:// www.journalofdairyscience.org/). Other authors have reported a darkening of the rumen epithelium when ruminants were fed high amounts of $\mathrm{FeSO}_{4}$ or soil containing large amounts of Fe (Hamada et al., 1969; Standish et al., 1971; McGuire et al., 1985). This discoloration, in combination with the minimal differences observed in DMT1 protein levels even in the face of excessive dietary $\mathrm{Fe}$, suggests that the rumen may have been buffering the intestine from high levels of Fe. It is possible that $\mathrm{Fe}$ was precipitating with $\mathrm{S}$ in the rumen; however, it is unknown whether this complex would dissociate in the abomasum, allowing $\mathrm{Fe}$ to become soluble again in the distal gastrointestinal tract, or remain complexed, effectively reducing the amount of available Fe in these diets. This may offer an explanation as to the unexpected lack of differences in Dmt1 $(-I R E$ and $+I R E)$ and Zip14 gene expression due to dietary Fe concentration.

Excessive dietary Fe negatively affected the intestinal health of calves as evidenced by increased mannitol flux and decreased TER of proximal duodenum sections mounted on Ussing chambers. We have previously observed a similar increase in intestinal permeability in young pigs when dietary $\mathrm{Fe}$ was increased from 20 to 120 or $520 \mathrm{mg}$ of $\mathrm{Fe} / \mathrm{kg}$ of DM (Hansen, 2008). We hypothesized that the mechanism of high-Fe induced epithelium injury was due to oxidative damage and subsequent lipid peroxidation. In the heart, the expression of the genes encoding for the antioxidants Sod1 and Sod2 was increased due to dietary Fe. Although heart $\mathrm{Fe}$ only tended to be higher in calves fed high $\mathrm{Fe}$, this difference may have been enough to cause oxidative stress and induce expression of the Sod genes. Previous work has demonstrated that GSH-Px activity is increased in human heart in response to oxidative stress (Schimke et al., 2000); however, in the present study, neither GSH-Px activity nor MDA concentration was affected by dietary Fe concentration. Conversely, duodenal and liver MDA concentrations were increased in pigs fed 120 or $520 \mathrm{mg}$ of $\mathrm{Fe} / \mathrm{kg}$ of DM (A. J. Moeser, S. L. Hansen, and J. W. Spears; unpublished data). Collectively, our data suggest that high dietary Fe causes damage to intestinal epithelium, although the mechanism behind this damage is unclear at the present time. Increased permeability of the intestine to foreign pathogens and unregulated absorption of minerals and other dietary components may have important repercussions on overall animal health and nutritional status; therefore, further research into this finding is warranted.

In conclusion, the Fe signaling cascade of hepcidin and ferroportin was altered by feeding a diet high in $\mathrm{Fe}$ to weaned calves. Excessive dietary $\mathrm{Fe}$ also tended to reduce intestinal DMT1 protein, which correlated with decreased intestinal concentrations of $\mathrm{Mn}$, suggesting that $\mathrm{Fe}$ and $\mathrm{Mn}$ may compete for transport via DMT1 in the bovine. Unexpectedly, excessive dietary Fe caused increased mRNA expression of both Sod1 and Sod2 in heart and increased permeability of the proximal duodenum, although the mechanism behind this is unclear. Because ruminant diets are often high in $\mathrm{Fe}$, whether from soil ingestion or consumption of feedstuffs naturally high in Fe, further research into the implications of high dietary Fe on the metabolism of other trace metals as well as gut health is needed.

\section{REFERENCES}

Andrews, N. C. 1999. The iron transporter DMT1. Int. J. Biochem. Cell Biol. 31:991-994.

Chua, A. C., and E. H. Morgan. 1997. Manganese metabolism is impaired in the Belgrade laboratory rat. J. Comp. Physiol. [B] 167:361-369.

Conrad, M. E., J. N. Umbreit, E. G. Moore, L. N. Hainsworth, M. Porubcin, M. J. Simovich, M. T. Nakada, K. Dolan, and M. D. Garrick. 2000. Separate pathways for cellular uptake of ferric and ferrous iron. Am. J. Physiol. Gastrointest. Liver Physiol. 279:G767-G774.

Ganz, T., and E. Nemeth. 2006. Regulation of iron acquisition and iron distribution in mammals. Biochim. Biophys. Acta 1763:690-699. 
Garrick, M. D., K. G. Dolan, C. Horbinski, A. J. Ghio, D. Higgins, M. Porubcin, E. G. Moore, L. N. Hainsworth, J. N. Umbreit, M. E. Conrad, L. Feng, A. Lis, J. A. Roth, S. Singleton, and L. M. Garrick. 2003. DMT1: A mammalian transporter for multiple minerals. Biometals 16:41-54.

Garrick, M. D., H. C. Kuo, F. Varga, S. Singleton, L. Zhao, J. Smith, P. Paradkar, J. A. Roth, and L. M. Garrick. 2006. Comparison of mammalian cell lines expressing distinct isoforms of divalent metal transporter 1 in a tetracycline-regulated fashion. Biochem. J. 398:539-546.

Gengelbach, G. P., J. D. Ward, and J. W. Spears. 1994. Effect of dietary copper, iron and molybdenum on growth and copper status of beef cows and calves. J. Anim. Sci. 72:2722-2727.

Greene, L. W. 2000. Designing mineral supplements for beef cattle. J. Anim. Sci. 77 (Suppl. 1):125. (Abstr.)

Gunshin, H., B. Mackenzie, U. V. Berger, Y. Gunshin, M. F. Romero, W. F. Boron, S. Nussberger, J. L. Gollan, and M. A. Hediger 1997. Cloning and characterization of a mammalian protoncoupled metal-ion transporter. Nature 388:482-488.

Hamada, T., S. Maeda, and K. Kameoka. 1969. Effects of minerals on formation of color in the rumen epithelium of kids. J. Dairy Sci. 53:588-591.

Hansen, S. L. 2008. Nutritional Interrelationships between Iron, Copper and Manganese in Domestic Livestock. PhD Thesis. North Carolina State University, Raleigh.

Hansen, S. L., M. S. Ashwell, L. R. Legleiter, R. S. Fry, K. E. Lloyd, and J. W. Spears. 2009. The addition of high manganese to a copper-deficient diet further depresses copper status and growth of cattle. Br. J. Nutr. 101:1068-1078.

Hansen, S. L., and J. W. Spears. 2009. Bioaccessibility of iron from soil is increased by silage fermentation. J. Dairy Sci. 92:2896-2905.

Harrison, G. A., K. A. Dawson, and R. W. Hemken. 1992. Effects of high iron and sulfate ion concentrations on dry matter digestion and volatile fatty acid production by ruminal microorganisms. J. Anim. Sci. 70:1188-1194.

Hubert, N., and M. W. Hentze. 2002. Previously uncharacterized isoforms of divalent metal transporter (DMT1)-1: Implications for regulation and cellular function. Proc. Natl. Acad. Sci. USA 99:12345-12350.

Janovick-Guretzky, N. A., H. M. Dann, D. B. Carlson, M. R. Murphy, J. J. Loor, and J. K. Drackley. 2007. Housekeeping gene expression in bovine liver is affected by physiological state, feed intake, and dietary treatment. J. Dairy Sci. 90:2246-2252.

Johnson, D. M., S. Yamaji, J. Tennant, S. K. Srai, and P. A. Sharp. 2005. Regulation of divalent metal transporter expression in human intestinal epithelial cells following exposure to non-haem iron. FEBS Lett. 579:1923-1929.

Kerr, B. J., C. J. Ziemer, T. E. Weber, S. L. Trabue, B. L. Bearson, G. C. Shurson, and M. W. Whitney. 2008. Comparative sulfur analysis using thermal combustion or inductively coupled plasma methodology and mineral composition of common livestock feedstuffs. J. Anim. Sci. 86:2377-2384.

Koong, L.-J., M. B. Wise, and E. R. Barrick. 1970. Effect of elevated dietary levels of iron on the performance and blood constituents of calves. J. Anim. Sci. 31:422-427.

Knutson, M. D., M. Oukka, L. M. Koss, F. Aydemir, and M. Wessling-Resnick. 2005. Iron release from macrophages after erythrophagocytosis is up-regulated by ferroportin 1 overexpression and down-regulated by hepcidin. Proc. Natl. Acad. Sci. USA 102:1324-1328.

McGuire, S. O., W. J. Miller, R. P. Gentry, M. W. Neathery, S. Y. Ho, and D. M. Blackmon. 1985. Influence of high dietary iron as ferrous carbonate and ferrous sulfate on iron metabolism in young calves. J. Dairy Sci. 68:2621-2628.

Moeser, A. J., C. Vander Klok, K. A. Ryan, J. G. Wooten, D. Little, V. L. Cook, and A. T. Blikslager. 2007. Stress signaling pathways activated by weaning mediate intestinal dysfunction in the pig. Am. J. Physiol. Gastrointest. Liver Physiol. 292:G173-G181.

Nemeth, E., M. S. Tuttle, J. Powelson, M. B. Vaughn, A. Donovan, D. Mcvey Ward, T. Ganz, and J. Kaplan. 2004. Hepcidin regulates cellular iron efflux by binding to ferroportin and inducing its internalization. Science 306:2090-2093.

NRC. 1996. Nutrient Requirements of Beef Cattle. 7th ed. National Academy Press, Washington, DC.

NRC. 2001. Nutrient Requirements of Dairy Cattle. 7th ed. National Academy Press, Washington, DC.

Paglia, D. E., and W. N. Valentine. 1967. Studies on the quantitative and qualitative characterization of erythrocyte glutathione peroxidase. J. Lab. Clin. Med. 70:158-169.

Schimke, I., M. Schikora, R. Meyer, H-P. Dübel, D. Modersohn, F. X. Kleber, and G. Baumann. 2000. Oxidative stress in the human heart is associated with changes in the antioxidative defense as shown after heart transplantation. Mol. Cell. Biochem. 204:89 96.

Sigma Chemical Co. 1990. The quantitative, colorimetric determination of total hemoglobin. Tech. Bull. no. 525. Revised ed. Sigma Chemical, St. Louis, MO.

Standish, J. F., C. B. Ammerman, A. Z. Palmer, and C. F. Simpson. 1971. Influence of dietary iron and phosphorus on performance, tissue mineral composition and mineral absorption in steers. J. Anim. Sci. 33:171-178.

Standish, J. F., C. B. Ammerman, C. F. Simpson, F. C. Neal, and A. Z. Palmer. 1969. Influence of graded levels of dietary iron, as ferrous sulfate, on performance and tissue mineral composition of steers. J. Anim. Sci. 29:496-503.

Wessling-Resnick, M. 2006. Iron imports. III. Transfer of iron from the mucosa into circulation. Am. J. Physiol. Gastrointest. Liver Physiol. 290:G1-G6. 